\title{
Effects of dexmedetomidine on inflammatory factors, T lymphocyte subsets and expression of NF- $\kappa B$ in peripheral blood mononuclear cells in patients receiving radical surgery of colon carcinoma
}

\author{
KUN WANG and CHENGWEN LI
}

Department of Anesthesiology, Jining No. 1 People's Hospital, Jining, Shandong 272011, P.R. China

Received December 14, 2017; Accepted February 16, 2018

DOI: $10.3892 / \mathrm{ol} .2018 .8205$

\begin{abstract}
The effects of dexmedetomidine on inflammatory factors, $\mathrm{T}$ lymphocyte subsets and expression of nuclear factor- $\kappa \mathrm{B}(\mathrm{NF}-\kappa \mathrm{B})$ in peripheral blood mononuclear cells in patients receiving radical surgery of colon carcinoma were investigated. A total of 141 patients receiving radical surgery of colon carcinoma from January 2014 to April 2017 were divided into two groups randomly. The patients in the treatment group were given dexmedetomidine, while the patients in the control group were treated with saline. Results showed that there were no significant differences in preoperative levels of NF- $\mathrm{NB}$, sICAM-1 and IL- 8 between the two groups. However, the above three indexes of the groups were all significantly increased at 0.5 and $24 \mathrm{~h}$ after operation, and the results showed that the control group had a higher degree of increase $(\mathrm{P}<0.05)$. It was also found that the changes in levels of IL- 6 and CRP in patients were the same as those of the above three indexes; in other words, the degree of the increase in the control group was significantly higher than that in the treatment group after operation. Moreover, it was found that there was little difference in the preoperative Ramsay score of patients between the two groups. The scores at 0.5 and $12 \mathrm{~h}$ after operation in the treatment group were significantly higher than those in the control group $(\mathrm{P}<0.05)$. It was also found that the intraoperative and postoperative dosages of fentanyl in the treatment group were significantly less than those in the control group $(\mathrm{P}<0.05)$. We can conclude that the application of dexmedetomidine during anesthesia in patients receiving radical operation of colon carcinoma has a better clinical treatment effect, which can reduce the secretion of inflammatory
\end{abstract}

Correspondence to: Dr Chengwen Li, Department of Anesthesiology, Jining No. 1 People's Hospital, 6 Jiankang Road, Jining, Shandong 272011, P.R. China

E-mail: lichwen2008@126.com

Key words: dexmedetomidine, colon carcinoma, inflammatory factors, $\mathrm{T}$ lymphocyte subsets, peripheral blood mononuclear cells factors, decrease the inhibition of immunity and reduce the use of fentanyl.

\section{Introduction}

Patients receiving radical operation of colon carcinoma need anesthesia during the surgical treatment $(1,2)$. At present, dexmedetomidine, as a new type of adrenergic receptor agonist, is increasingly widely used in the field of anesthesia (3-5). The drug has been commonly used as the preoperative sedative, regional anesthesia adjuvant and general anesthesia adjuvant $(6,7)$. It is clinically found that the drug also has an anti-inflammatory effect (8-10). Therefore, 141 patients receiving radical operation of colon carcinoma in Jining No. 1 People's Hospital (Jining, China) from January 2014 to April 2017 were selected in this study, and dexmedetomidine anesthesia was induced, so as to explore the anti-inflammatory and immune effects of the sedative, and provide a more scientific clinical basis.

\section{Patients and methods}

General data. A total of 141 patients receiving radical operation of colon carcinoma in Jining No. 1 People's Hospital (Shandong, China) from January 2014 to April 2017 were collected, including 69 cases in the control group and 72 cases in the treatment group. There were 33 males and 36 females in the control group, and 36 males and 36 females in the treatment group. In the control group, they were aged 34-67 years with an average age of $45.3 \pm 5.0$ years, and in the treatment group, they were aged 35-69 years with an average age of $42.5 \pm 4.3$ years. Patients in the two groups were all in I-II of American Society of Anesthesiologists (ASA) grade. This study was approved by the Ethics Committee of Jining No. 1 People's Hospital. Signed written informed consents were obtained from all patients or their guardians before the study. Exclusion criteria: Patients with damage in heart, liver or kidney, or systemic immune system diseases.

Methods. Before the operation, the patients were fasting for $12 \mathrm{~h}$ before anesthesia and general anesthesia was performed before the operation. The method of anesthesia induction is 
Table I. Comparison of general data between two groups (mean \pm SD).

\begin{tabular}{lcccccc}
\hline Group & $\begin{array}{c}\text { Age } \\
\text { (years })\end{array}$ & $\begin{array}{c}\text { Body weight } \\
(\mathrm{kg})\end{array}$ & $\begin{array}{c}\text { ASA } \\
\text { grade }\end{array}$ & $\begin{array}{c}\text { Anesthesia time } \\
(\mathrm{min})\end{array}$ & $\begin{array}{c}\text { Operation time } \\
(\mathrm{min})\end{array}$ & $\begin{array}{c}\text { Amount of bleeding } \\
(\mathrm{ml})\end{array}$ \\
\hline Treatment group & $42.5 \pm 4.3$ & $52 \pm 3.5$ & I-II & $109.2 \pm 7.4$ & $98.7 \pm 4.3$ & $59.2 \pm 3.2$ \\
Control group & $45.3 \pm 5.0$ & $56 \pm 4.3$ & I-II & $110.5 \pm 7.4$ & $99.3 \pm 4.8$ & $58.8 \pm 3.0$ \\
\hline
\end{tabular}

Table II. Effects of NF- $\kappa$ B in peripheral blood mononuclear cells and serum sICAM-1 and IL-8 levels in two groups (mean \pm SD).

\begin{tabular}{|c|c|c|c|c|}
\hline Group & Time & $N F-\kappa B(U / 1)$ & sICAM-1 (mg/l) & $\mathrm{IL}-8(\mathrm{pg} / \mathrm{ml})$ \\
\hline \multirow[t]{3}{*}{ Treatment group } & Preoperative & $24.56 \pm 1.98$ & $320.8 \pm 8.6$ & $19.2 \pm 1.0$ \\
\hline & $0.5 \mathrm{~h}$ after operation & $33.79 \pm 2.65^{\mathrm{a}}$ & $507.2 \pm 7.5^{\mathrm{a}}$ & $45.7 \pm 2.7^{\mathrm{a}}$ \\
\hline & $24 \mathrm{~h}$ after operation & $28.31 \pm 2.51^{\mathrm{a}}$ & $498.8 \pm 10.0^{\mathrm{a}}$ & $24.5 \pm 1.9^{\mathrm{a}}$ \\
\hline \multirow[t]{3}{*}{ Control group } & Preoperative & $25.06 \pm 2.48$ & $334.3 \pm 6.9$ & $19.8 \pm 2.8$ \\
\hline & $0.5 \mathrm{~h}$ after operation & $42.59 \pm 3.65^{\mathrm{a}, \mathrm{b}}$ & $588.5 \pm 8.6^{\mathrm{a}, \mathrm{b}}$ & $59.8 \pm 3.0^{\mathrm{a}, \mathrm{b}}$ \\
\hline & $24 \mathrm{~h}$ after operation & $32.32 \pm 2.86^{\mathrm{a}, \mathrm{b}}$ & $543.1 \pm 9.5^{\mathrm{a}, \mathrm{b}}$ & $34.3 \pm 2.8^{\mathrm{a}, \mathrm{b}}$ \\
\hline
\end{tabular}

${ }^{\mathrm{a}}$ Compared with that before operation, $\mathrm{P}<0.05$; ${ }^{\mathrm{b}}$ compared with that in treatment group, $\mathrm{P}<0.05$.

as follows: The patients were given intravenous injection of midazolam $(0.05 \mathrm{mg} / \mathrm{kg})$, vecuronium $(0.1 \mathrm{mg} / \mathrm{kg})$, etomidate $(0.3 \mathrm{mg} / \mathrm{kg})$ and fentanyl $(1.0 \mu \mathrm{g} / \mathrm{kg})$. During ventilation, end-tidal partial pressure of carbon dioxide (PETCO2) was set at 35-45 $\mathrm{mmHg}$ and fentanyl was administered via veno-micropump target control with the infusion rate of $0.03-0.2 \mu \mathrm{g} /(\mathrm{kg} \cdot \mathrm{min})$. The tidal volume of the ventilator was set at $8-10 \mathrm{ml} / \mathrm{kg}$, with a frequency of $12-16$ times/min, and PETCO2 of 35-45 mmHg. The infusion rate of fentanyl was controlled to adjust the depth of anesthesia. Intravenous injection of urapidil or ephedrine was selected according to the change in SBP value. Sevoflurane inhalation was discontinued following the completion of operation and fentanyl $(0.5 \mu \mathrm{g} / \mathrm{kg})$ was administered intravenously after operation for systemic analgesia. The patients in the treatment group were given pump infusion of dexmedetomidine $[1 \mu \mathrm{g} / \mathrm{kg}$ over $10-15 \mathrm{~min}$ as a loading dose; then the pump flow rate was set as $1 \mu \mathrm{g} /$ $(\mathrm{kg} \cdot \mathrm{h})$ ] before operation, while the patients in the control group received pump injection of the same amount of normal saline.

Evaluation of the efficacy. Ramsay sedation score: Patients were scored before operation and at $0.5,12$ and $24 \mathrm{~h}$ after operation, respectively. Patients with irritability and restlessness: 1 point; patients who were cooperative and quiet: 2 points; patients with lethargy and obeying orders: 3 points, patients who could be awakened during sleep: 4 points; patients with slow reaction when being called: 5 points; patients who could not be awakened when being called: 6 points.

Observational indexes. The levels of nuclear factor- $\kappa \mathrm{B}$ $(\mathrm{NF}-\kappa \mathrm{B})$ in peripheral blood mononuclear cells, serum soluble intercellular adhesion molecule-1 (sICAM-1), interleukin-8 (IL-8), serum IL-6, tumor necrosis factor- $\alpha$ (TNF- $\alpha$ ) and $\mathrm{C}$-reactive protein (CRP) of patients in the two groups were observed during perioperative period. Besides, the levels of T lymphocyte subsets of patients in two groups were observed by flow cytometry. The dosages of fentanyl used during operation and after operation were recorded.

Statistical analysis. Data were processed by SPSS 17.0 software (SPSS, Inc., Chicago, IL, USA). Measurement data and counting data were expressed by mean \pm standard deviation (SD) and n, respectively, and t-test and chi-square test were used for intergroup comparison. $\mathrm{P}<0.05$ suggested that the difference was statistically significant.

\section{Results}

Comparison of general data between two groups. The general data of patients in the two groups were compared: In the treatment group, the average age was $42.5 \pm 4.3$ years, body weight was $52 \pm 3.5 \mathrm{~kg}$, ASA grade was I-II, anesthesia time $109.2 \pm 7.4 \mathrm{~min}$, operation time $98.7 \pm 4.3 \mathrm{~min}$, and amount of bleeding was $59.2 \pm 3.2 \mathrm{ml}$; in the control group, the average age was $45.3 \pm 5.0$ years, body weight $56 \pm 4.3 \mathrm{~kg}$, ASA grade I-II, anesthesia time $110.5 \pm 7.4 \mathrm{~min}$, operation time $99.3 \pm 4.8 \mathrm{~min}$, and amount of bleeding was $58.8 \pm 3.0 \mathrm{ml}$. The anesthesia time and the amount of bleeding in the two groups were similar (Table I).

Effects of $N F-\kappa B$ in peripheral blood mononuclear cells and serum sICAM-1 and IL-8 levels in the two groups. There were no significant differences in the preoperative levels of $\mathrm{NF}-\kappa \mathrm{B}, \mathrm{sICAM}-1$ and IL-8 in patients between the two groups. However, they were increased and then decreased at 0.5 and $24 \mathrm{~h}$ after operation; the contents of three indexes of patients in both groups were significantly increased at two time-points after operation, and the degree of the increase in control group 
Table III. Comparison of serum levels of IL-6, TNF- $\alpha$ and CRP in patients between two groups (mean \pm SD).

\begin{tabular}{|c|c|c|c|c|}
\hline Group & Time & IL-6 (pg/ml) & $\mathrm{TNF}-\alpha(\mathrm{pg} / \mathrm{ml})$ & $\mathrm{CRP}(\mathrm{mg} / \mathrm{l})$ \\
\hline \multirow[t]{3}{*}{ Treatment group } & Preoperative & $3.25 \pm 0.98$ & $16.27 \pm 2.21$ & $4.45 \pm 0.32$ \\
\hline & $0.5 \mathrm{~h}$ after operation & $70.56 \pm 3.21^{\mathrm{a}}$ & $15.02 \pm 2.06$ & $5.78 \pm 0.19^{\mathrm{a}}$ \\
\hline & $24 \mathrm{~h}$ after operation & $60.72 \pm 2.98^{\mathrm{a}}$ & $19.72 \pm 2.34$ & $4.21 \pm 0.12$ \\
\hline \multirow[t]{3}{*}{ Control group } & Preoperative & $3.69 \pm 0.65$ & $16.83 \pm 3.01$ & $4.29 \pm 0.18$ \\
\hline & $0.5 \mathrm{~h}$ after operation & $90.56 \pm 3.65^{\mathrm{a}, \mathrm{b}}$ & $16.75 \pm 2.10$ & $8.12 \pm 0.21^{\mathrm{a}, \mathrm{b}}$ \\
\hline & $24 \mathrm{~h}$ after operation & $67.97 \pm 3.98^{\mathrm{a}, \mathrm{b}}$ & $18.98 \pm 2.03$ & $4.54 \pm 0.32$ \\
\hline
\end{tabular}

${ }^{\mathrm{a}}$ Compared with that before operation, $\mathrm{P}<0.05$; ${ }^{\mathrm{b}}$ compared with that in treatment group, $\mathrm{P}<0.05$.

Table IV. Comparison of Ramsay scores between two groups (mean $\pm \mathrm{SD}$ ).

\begin{tabular}{lccccc}
\hline Group & Case & Before operation & 0.5 h after operation & 12 h after operation & 24 h after operation \\
\hline Treatment group & 72 & $1.97 \pm 0.21$ & $4.13 \pm 0.43$ & $2.34 \pm 0.17$ & $2.05 \pm 0.19$ \\
Control group & 69 & $1.98 \pm 0.15$ & $2.59 \pm 0.18^{\mathrm{a}}$ & $1.99 \pm 0.10^{\mathrm{a}}$ & $2.06 \pm 0.12$ \\
\hline
\end{tabular}

${ }^{a}$ Compared with the treatment group, $\mathrm{P}<0.05$.

was significantly higher than that of the treatment group $(\mathrm{P}<0.05)$, with statistical significance (Table II).

Comparisons of serum IL-6, TNF- $\alpha$ and CRP levels in patients between two groups. In the treatment group, the levels of IL-6, TNF- $\alpha$ and CRP before treatment were 3.25 \pm 0.98 , $16.27 \pm 2.21 \mathrm{pg} / \mathrm{ml}$ and $4.45 \pm 0.32 \mathrm{mg} / \mathrm{l}$, respectively; the levels of IL-6, TNF- $\alpha$ and CRP at $0.5 \mathrm{~h}$ after operation were $70.56 \pm 3.21,15.02 \pm 2.06 \mathrm{pg} / \mathrm{ml}$ and $5.78 \pm 0.19 \mathrm{mg} / 1$, respectively; and the levels of the three indexes at $24 \mathrm{~h}$ after operation were $60.72 \pm 2.98,19.72 \pm 2.34 \mathrm{pg} / \mathrm{ml}$ and $3.21 \pm 0.12 \mathrm{mg} / \mathrm{l}$, respectively. In the control group, the levels of the three indexes before operation were $3.69 \pm 0.65,16.83 \pm 3.01 \mathrm{pg} / \mathrm{ml}$ and $4.29 \pm 0.18 \mathrm{mg} / \mathrm{l}$, respectively; the levels of the three indexes at $0.5 \mathrm{~h}$ after operation were $90.56 \pm 3.65,16.75 \pm 2.10 \mathrm{pg} / \mathrm{ml}$ and $8.12 \pm 0.21 \mathrm{mg} / \mathrm{l}$, respectively; and the levels of the three indexes at $24 \mathrm{~h}$ after operation were $67.97 \pm 3.98,18.98 \pm 2.03 \mathrm{pg} / \mathrm{ml}$ and $4.54 \pm 0.32 \mathrm{mg} / \mathrm{l}$, respectively. It was found that the levels of IL- 6 in two groups were increased at 0.5 and $24 \mathrm{~h}$ after operation, and the levels of IL- 6 in the control group were significantly higher than that in the treatment group. The postoperative level of CRP was higher than that before operation, and the postoperative level in the control group was higher than that in the treatment group (Table III).

Comparison of Ramsay scores between two groups. The preoperative Ramsay scores of patients in the treatment group and the control group were $1.97 \pm 0.21$ and $1.98 \pm 0.15$ points, respectively. The Ramsay scores $0.5 \mathrm{~h}$ after operation of patients in two groups were $4.13 \pm 0.43$ and $2.59 \pm 0.18$ points, respectively. The Ramsay scores at $12 \mathrm{~h}$ after operation of patients in two groups were $2.34 \pm 0.17$ and $1.99 \pm 0.10$ points, respectively. The Ramsay scores at $24 \mathrm{~h}$ after operation of patients in two groups were $2.05 \pm 0.19$ and $2.06 \pm 0.12$ points,

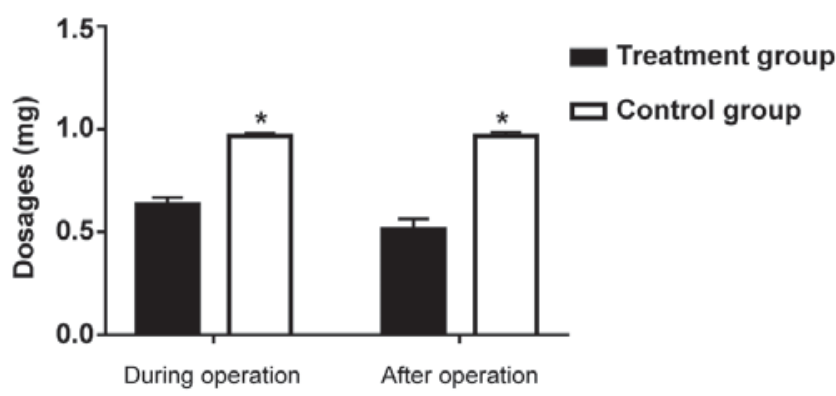

Figure 1. Comparisons of the dosages of fentanyl in patients between two groups. ${ }^{*} \mathrm{P}<0.05$, compared with treatment group.

respectively. The results showed that the Ramsay scores of patients in the treatment group were higher than those in the control group at 0.5 and $12 \mathrm{~h}$ after operation, and the differences were significant between the two groups (Table IV).

Changes in levels of T lymphocyte subsets in patients during perioperative period between two groups. The levels of $\mathrm{T}$ lymphocyte subsets had no difference between the two groups at the first time point. The $\mathrm{CD}^{+}{ }^{+} \mathrm{T}, \mathrm{CD} 4^{+} \mathrm{T}, \mathrm{CD} 4^{+} \mathrm{T} / \mathrm{CD} 8^{+} \mathrm{T}$, Th1 and Th1/Th2 in two groups were lower at T2 and T3 than those at $\mathrm{T} 0$, and the Treg values at $\mathrm{T} 2$ and $\mathrm{T} 3$ were significantly higher than those at T0. It was also found that the indexes of $\mathrm{CD}^{+}{ }^{+} \mathrm{T}, \mathrm{CD} 4^{+} \mathrm{T}, \mathrm{CD} 4^{+} \mathrm{T} / \mathrm{CD}^{+} \mathrm{T}$, Th1 and $\mathrm{Th} 1 / \mathrm{Th} 2$ in the treatment group were lower than those in the control group, and the Treg value was higher than that in the control group $(\mathrm{P}<0.05)$ (Table V).

Comparison of the dosages of fentanyl in patients between two groups. The fentanyl dosages during operation and after operation in the treatment group were $0.63 \pm 0.11$ and 
$0.52 \pm 0.09 \mathrm{mg}$ respectively, and the fentanyl dosages during operation and after operation in the control group were $0.98 \pm 0.21$ and $0.99 \pm 0.19 \mathrm{mg}$ respectively, suggesting that the fentanyl dosage whether during operation or after operation in the treatment group was lower than that in the control group $(\mathrm{P}<0.05)$ (Fig. 1).

\section{Discussion}

Inflammation, as a physiological disease, often occurs in the body. When inflammation occurs in the body, it will lead to changes in blood vessels, cells and other tissues $(11,12)$. Clinical studies have found that the use of anesthetics in the body can act on inflammatory factors, such as mononuclear macrophages, and also affect inflammatory mediators $(13,14)$. The research on anti-inflammatory effect of all anesthetics is based on a variety of inflammatory factors. The most widely used inflammatory factors are IL-6, TNF- $\alpha$ and IL-8. IL-6 and IL- 8 are produced by mononuclear macrophages in the body, while TNF- $\alpha$ is secreted by neutrophils. A variety of inflammatory factors can affect the neutrophil chemotaxis and induce allergic reactions, leading to chemotaxis of $\mathrm{T}$ cells, which can promote the immune response in the body to a certain extent $(15,16)$.

$\mathrm{NF}-\mathrm{\kappa B}$ is a key nuclear transcription factor in the body and plays an important role in the immune and inflammation processes. When the body is stimulated by inflammatory

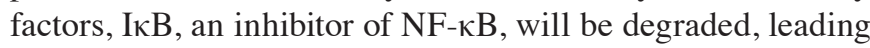
to over-secretion of NF- $\kappa \mathrm{B}$ in the body; the excessive NF- $\kappa \mathrm{B}$ will be transferred into the nucleus, leading to gene expression (17).

ICAM-1 is widely used in antigen production and leukocyte infiltration process, and it is widely distributed in lymphocytes. As a kind of multifunctional adhesion molecule, it is also involved in the process of body immunity. T cell subsets have been clinically proven to be important indexes of immune disorders of the body, and Treg is a subset of T cells that can inhibit the immune response in cancer patients. Clinical studies have found that dexmedetomidine acts on the blue plaque in brain, which can reduce norepinephrine secretion, inhibit oxidative stress, and inhibit the occurrence of inflammation (18-20).

In this study the degree of the increase in the inflammatory factors at 0.5 and $24 \mathrm{~h}$ after operation in the treatment group was significantly lower than those in the control group $(\mathrm{P}<0.05)$. Patients in two groups had the same factor levels before operation, indicating that the dexmedetomidine anesthesia can significantly inhibit the secretion of inflammatory factors and inhibit the release of inflammatory mediators. Clinical studies have found that when dexmedetomidine takes effect, the patient's central nervous system receptors will be affected, and the norepinephrine will be inhibited, leading to less stress response in patients and decreased secretion of catecholamine in adrenergic receptor and glucocorticoid receptor in patients, which ultimately inhibits the production of inflammatory factors. In this study, it was also found that the sedation in the treatment group was better than that in the control group $(\mathrm{P}<0.05)$. Dexmedetomidine can act on the nerve center of the body to reduce the release of norepinephrine and increase the threshold of excitement. 
In conclusion, the application of dexmedetomidine in patients receiving radical operation of colon carcinoma has a better clinical effect, which can reduce the production of inflammatory factors, decrease the inhibition of $\mathrm{T}$ lymphocyte subsets, and lower the impact on NF- $\mathrm{NB}$ in peripheral blood mononuclear cells, with a higher clinical therapeutic value.

\section{Acknowledgements}

Not applicable.

\section{Funding}

No funding was received.

\section{Availability of data and materials}

All data generated or analyzed during this study are included in this published article.

\section{Authors' contributions}

KW designed the study and prepared the manuscript. CL collected and analysed the data. All authors read and approved the final manuscript.

\section{Ethics approval and consent to participate}

This study was approved by the Ethics Committee of Jining No. 1 People's Hospital (Jining, China). Signed written informed consents were obtained from all patients or their guardians before the study.

\section{Consent for publication}

Not applicable.

\section{Competing interests}

The authors declare that they have no competing interests.

\section{References}

1. Walker SM, Grafe M and Yaksh TL: Intrathecal clonidine in the neonatal rat: Dose-dependent analgesia and evaluation of spinal apoptosis and toxicity. Anesth Analg 115: 450-460, 2012.

2. Ozcengiz D, Unlügenç H, Günes Y and Karacaer F: The effect of dexmedetomidine on bispectral index monitoring in children. Middle East J Anaesthesiol 21: 613-618, 2012.

3. Bannister CF, Brosius KK, Sigl JC, Meyer BJ and Sebel PS The effect of bispectral index monitoring on anesthetic use and recovery in children anesthetized with sevoflurane in nitrous oxide. Anesth Analg 92: 877-881, 2001.

4. Li HL, She SZ, Yan Y and Zhu SM: Effect of dexmedetomidine on bispectral index and auditory evoked potential index during anesthesia with target controlled infusion of propofol and remifentanyl. Zhejiang Da Xue Xue Bao Yi Xue Ban 39: 84-88, 2010 (In Chinese)
5. Ishibashi C, Hayashida M, Sugasawa Y, Yamaguchi K, Tomita N, Kajiyama Y and Inada E: Effects of dexmedetomidine on hemodynamics and respiration in intubated, spontaneously breathing patients after endoscopic submucosal dissection for cervical esophageal or pharyngeal cancer. J Anesth 30: 628-636, 2016.

6. Lin H, Faraklas I, Sampson C, Saffle JR and Cochran A: Use of dexmedetomidine for sedation in critically ill mechanically ventilated pediatric burn patients. J Burn Care Res 32: 98-103, 2011.

7. Zhao XN, Ran JH, Bajracharya AR and Ma MY: Effect of different doses of dexmedetomidine on median effective concentration of propofol for anesthesia induction: A randomized controlled trial. Eur Rev Med Pharmacol Sci 20: 3134-3143, 2016.

8. Valenza G, Akeju O, Pavone KJ, Citi L, Hartnack KE, Sampson A, Purdon PL, Brown EN and Barbieri R: Instantaneous monitoring of heart beat dynamics during anesthesia and sedation. J Comput Surg 1: 1-18, 2014.

9. Walker SM, Howard RF, Keay KA and Fitzgerald M: Developmental age influences the effect of epidural dexmedetomidine on inflammatory hyperalgesia in rat pups. Anesthesiology 102: 1226-1234, 2005.

10. Dong W, Chen MH, Yang YH, Zhang X, Huang MJ, Yang XJ and Wang HZ: The effect of dexmedetomidine on expressions of inflammatory factors in patients with radical resection of gastric cancer. Eur Rev Med Pharmacol Sci 21: 3510-3515, 2017.

11. Chu NJ, Armstrong TD and Jaffee EM: Nonviral oncogenic antigens and the inflammatory signals driving early cancer development as targets for cancer immunoprevention. Clin Cancer Res 21: 1549-1557, 2015.

12. Smit MA, Jaffee EM and Lutz ER: Cancer immunoprevention - the next frontier. Cancer Prev Res (Phila) 7: 1072-1080, 2014.

13. Kostopanagiotou G, Sidiropoulou T, Pyrsopoulos N, Pretto EA Jr, Pandazi A, Matsota P, Arkadopoulos N, Smyrniotis V and Tzakis AG: Anesthetic and perioperative management of intestinal and multivisceral allograft recipient in nontransplant surgery. Transpl Int 21: 415-427, 2008.

14. Nesković V: Preoperative assesment of the immunocompromised patient. Acta Chir Iugosl 58: 185-192, 2011.

15. Remotti H, Subramanian S, Martinez M, Kato T and Magid MS: Small-bowel allograft biopsies in the management of smallintestinal and multivisceral transplant recipients: Histopathologic review and clinical correlations. Arch Pathol Lab Med 136: 761-771, 2012.

16. Yuki K, Soriano SG and Shimaoka M: Sedative drug modulates T-cell and lymphocyte function-associated antigen-1 function. Anesth Analg 112: 830-838, 2011.

17. Alonso-Arias R, Moro-García MA, Vidal-Castiñeira JR, SolanoJaurrieta JJ, Suárez-García FM, Coto E and López-Larrea C: IL-15 preferentially enhances functional properties and antigen-specific responses of $\mathrm{CD} 4^{+} \mathrm{CD} 28^{\text {null }}$ compared to $\mathrm{CD} 4^{+} \mathrm{CD} 28^{+} \mathrm{T}$ cells Aging Cell 10: 844-852, 2011.

18. Can M, Gul S, Bektas S, Hanci V and Acikgoz S: Effects of dexmedetomidine or methylprednisolone on inflammatory responses in spinal cord injury. Acta Anaesthesiol Scand 53: 1068-1072, 2009.

19. Fang B, Li XQ, Bi B, Tan WF, Liu G, Zhang Y and Ma H: Dexmedetomidine attenuates blood-spinal cord barrier disruption induced by spinal cord ischemia reperfusion injury in rats. Cell Physiol Biochem 36: 373-383, 2015.

20. Bicer C, Esmaoglu A, Akin A and Boyaci A: Dexmedetomidine and meperidine prevent postanaesthetic shivering. Eur J Anaesthesiol 23: 149-153, 2006. International (CC BY-NC-ND 4.0) License. 